\title{
Plantlike Cadinane Sesquiterpenes from an Actinobacterial Mangrove Endophyte
}

Ding, Ling; Görls, Helmar ; Hertweck, Christian

Published in:

Magnetic Resonance in Chemistry

Link to article, DOI:

10.1002/mrc.5070

Publication date:

2021

Document Version

Peer reviewed version

Link back to DTU Orbit

Citation (APA):

Ding, L., Görls, H., \& Hertweck, C. (2021). Plantlike Cadinane Sesquiterpenes from an Actinobacterial Mangrove Endophyte. Magnetic Resonance in Chemistry, 59(1), 34-42. https://doi.org/10.1002/mrc.5070

\section{General rights}

Copyright and moral rights for the publications made accessible in the public portal are retained by the authors and/or other copyright owners and it is a condition of accessing publications that users recognise and abide by the legal requirements associated with these rights.

- Users may download and print one copy of any publication from the public portal for the purpose of private study or research.

- You may not further distribute the material or use it for any profit-making activity or commercial gain

- You may freely distribute the URL identifying the publication in the public portal

If you believe that this document breaches copyright please contact us providing details, and we will remove access to the work immediately and investigate your claim 
Ding Ling (Orcid ID: 0000-0001-8979-3104)

\section{Plant-like Cadinane Sesquiterpenes from an Actinobacterial Mangrove Endophyte}

Ling Ding, ${ }^{\mathrm{a}, \mathrm{b},{ }^{*}}$ Helmar Görls, ${ }^{\mathrm{c}}$ and Christian Hertweck ${ }^{\mathrm{a}, \mathrm{d}}$

${ }^{a}$ Leibniz Institute for Natural Product Research and Infection Biology - Hans Knöll Institute (HKI), Beutenbergstr. 11a, 07745 Jena, Germany

${ }^{b}$ Department of Biotechnology and Biomedicine, Technical University of Denmark, Sфltofts Plads, Bygning 221, DK-2800 Kgs. Lyngby, Denmark

${ }^{c}$ Institute for Inorganic and Analytical Chemistry, Friedrich Schiller University, Lessingstr. 8, 07743 Jena, Germany

${ }^{d}$ Faculty of Biological Sciences, Friedrich Schiller University Jena, 07737 Jena, Germany

* To whom correspondence should be addressed. Associate Prof. Ling Ding, Tel: + 4550333791.E-mail: $\underline{\text { lidi@ dtu.dk }}$

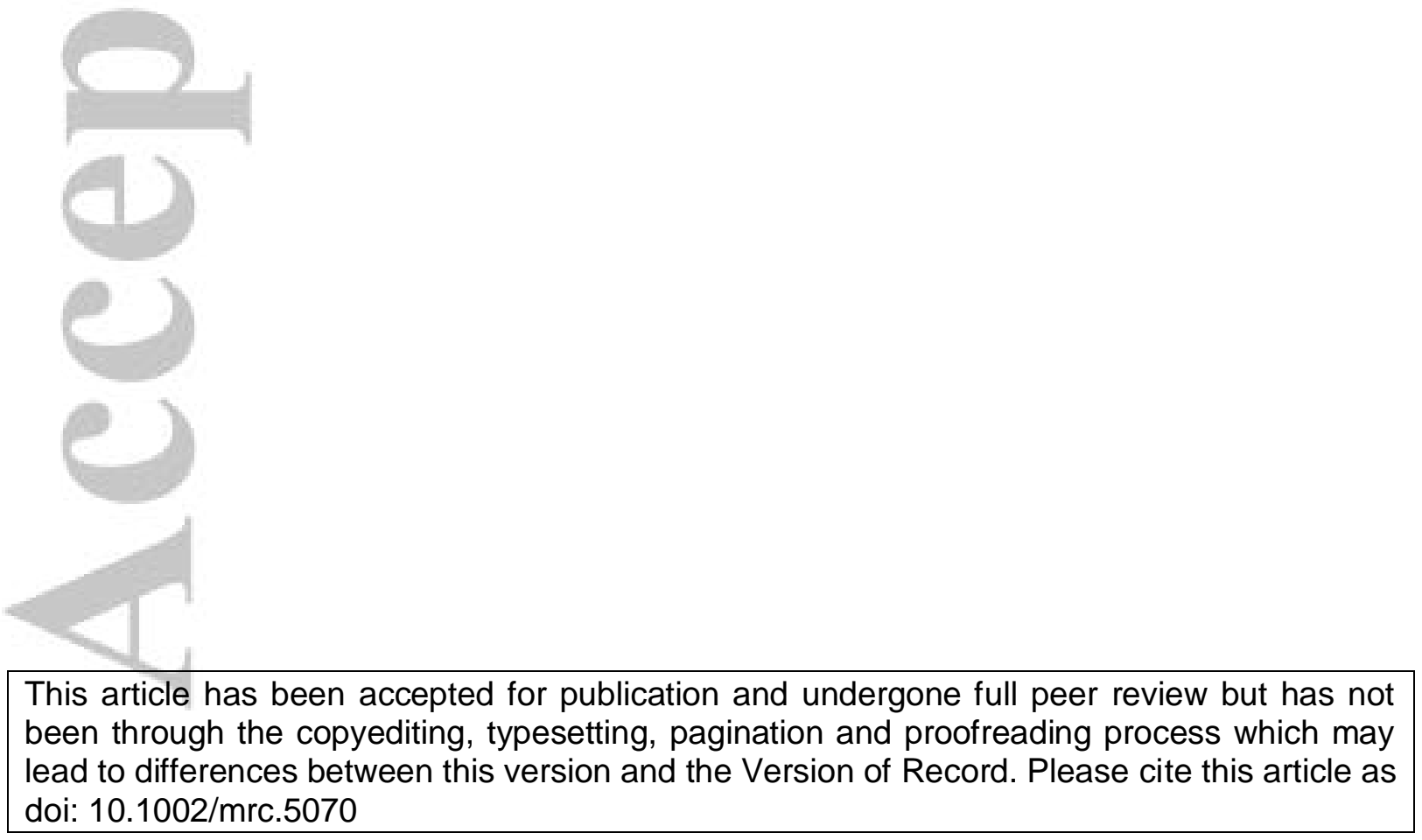




\begin{abstract}
Cadinanes are typical plant sesquiterpenes with a broad range of biological functions. We report the isolation of three cadinanes (1-3) from a bacterial endophyte (Streptomyces $\mathrm{sp}$. ) of the mangrove plant Bruguiera gymnorrhiza. The structures of two new cadinenens, (+)-11hydroxy-epicubenol (1) and (+)-12-hydroxy-epicubenol (2) were elucidated by NMR and mass spectrometry. The bacterial product (+)-11-hydroxy-epicubenol was elucidated to be an enantiomer of the plant product pubinernoid C. $(+)-12$-Hydroxy-epicubenol was established as a diastereomer of the basidiomycete product trichapargin A. In addition, a crystal structure analysis corroborated the structure and configuration of 5,11-epoxy-10-cadinanol (3), a cadinane cycloether initially described as a natural product from liverworth. The discovery of oxygenated cadinanes from a bacterial endophyte may set the basis for the production of cadinanes by bacterial fermentation.
\end{abstract}

KEYWORDS: NMR; 2D NMR; cadinane; endophyte; sesquiterpene; Streptomyces; terpene; epicubenol 


\section{INTRODUCTION}

Cadinanes (examples in Figure 1) constitute a large family of plant and fungal terpenes with characteristic decaline (cadinane, or cadalane) scaffolds that result from the C-1/C-6, C-5/C10 cyclization of farnesyl pyrophosphate. Depending on their architectures and substitution patterns, cadinane sesquiterpenoids play diverse biological functions or have pharmaceutically relevant bioactivities.

For example, $\gamma$-cadinene, $(+)$ - $\delta$-cadinene, and T-muurolol are volatiles that contribute to the bouquets of many plants, such as hops and Tagetes. ${ }^{[1]}$ Cadinene is the precursor of the herbivore defense compound gossypol in cotton. ${ }^{[2]}$ T-Cadinol is a larvicidal and antimycobacterial agent found in the bark of the Peruvian plant Swartzia polyphylla. ${ }^{[3]} \alpha-$ Cadinol from Taiwania cryptomerioides ${ }^{[4]}$ and (-)-(5R, 6R, 7S, 9R, 10S)-cadinan-3-ene-6,7diol from Eupatorium adenophorum leaves ${ }^{[5]}$ are cytotoxic against various cancer cell lines, and polygosumic acid inhibits the growth of drug-resistant Escherichia coli and Staphylococcus aureus (MRSA) strains. ${ }^{[6]}$ The most important seco-cadinane-derived drug is the antimalarial agent artemisinine. ${ }^{[7]}$ While artemisinine is traditionally obtained by extraction of Artemisia species, there is increasing interest in the semisynthesis of the drug from cadinane precursors such as artemisinic acid obtained by fermentation of recombinant yeast expressing plant genes. ${ }^{[8]}$

Microbial sources of cadinanes would be valuable for synthetic biology approaches, ${ }^{[9]}$ yet reports on such microbial sesquiterpenes are extremely scarce. At the time this study was conducted, few examples were $\gamma$-cadinenes from termite-associated fungus Termitomyces ${ }^{[10]}$ and

Chitinophaga pinensis, ${ }^{[11]}$ bacterial cadinene sesquiterpenes were an unspecified cadinene from Streptomyces citreus ${ }^{[12]}$ and $(-)-\delta$-cadinene as well as (+)-T-muurolol, the antipodes of 
the plant metabolites, $(+)$ - $\delta$-cadinene, and T-muurolol, were obtained by expression of cryptic sesquiterpene synthase from both Streptomyces clavuligerus and Roseiflexus castenholzii. ${ }^{[11,}$

13] T-muurolol and oxygenated congeners have also been reported as natural products from a marine Streptomyces isolate. ${ }^{[14]}$ Here we report on the isolation and structure elucidation of three cadinane-type sesquiterpenes, from a bacterial endophyte residing in the stem of the mangrove plant Bruguiera gymnorrhiza.

\section{RESULTS AND DISCUSSION}

In the course of searching for new secondary metabolites from bacterial endophytes inhabiting mangrove trees, ${ }^{[15]}$ we noted that the associated microbes are prolific producers of terpenoids, including sesquiterpenes bacaryolanes ${ }^{[16]}$ and kandenols $^{[17]}$ as well as indolosesquiterpenes. $^{[18]}$ A closer inspection of the metabolic profile of a Streptomyces sp. (JMRC:ST027706) isolated from the stem of Bruguiera gymnorrhiza revealed a range of terpenoids in the nonpolar fractions. The discovery of rare bacterial caryolanes ${ }^{[16]}$ from this strain encouraged us to elucidate the fraction of other essential oil components. Therefore, we fractionated extracts of the fermentation broth (200 L) by chromatography on Amberchrom 161c resin LC, silica gel, and Sephadex LH-20 columns, yielding pure 1 (1.4 mg), 2 (4.3 mg), and $3(7.9 \mathrm{mg})$.

The structures of 1-3 were elucidated by MS, NMR (Figure 2), and X-ray crystallography of $\mathbf{3}$ (Figure 3). The molecular formula of compound $\mathbf{1}$ was proposed to be $\mathrm{C}_{15} \mathrm{H}_{26} \mathrm{O}_{2}\left(\mathrm{~m} / \mathrm{z}[\mathrm{M}+\mathrm{H}]^{+}\right.$239.2006, $\left.\Delta-0.2 \mathrm{ppm}\right)$. The ${ }^{1} \mathrm{H}$ NMR spectrum of 1 shows signals from one olefinic proton $(\mathrm{H}-5, \delta 5.63)$, four methyl groups and signals from other aliphatic protons. The ${ }^{13} \mathrm{C}$ NMR spectrum revealed 15 carbon signals indicating $\mathbf{1}$ as a sesquiterpene. 
The COSY spectrum revealed key correlations between H-5 and H-6 (s, $\delta$ 1.84) and H-3 ( $\delta$ 2.08), $\mathrm{H}-6$ and $\mathrm{H}-7$ (s, $\delta 1.35)$, and $\mathrm{H}-7$ and $\mathrm{H}-8(2 \mathrm{H}, \delta 1.04, \delta 1.74)$, and further correlations between $\mathrm{H}-2$ and $\mathrm{H}-3$, and $\mathrm{H}-8$ and $\mathrm{H}-9$, which indicated a decaline spin system. Further analysis of HSQC and HMBC data supported $\mathbf{1}$ as a cadinene-type sequiterpene with a transfused cyclohexene ring. A relative lower chemical shift for C-3 $(\delta 26.6$, trans $>30 \mathrm{ppm})$ indicated a cis-decalin skeleton for $\mathbf{1}$. A large coupling constant $(11.1 \mathrm{~Hz})$ between H-6 and H-7 suggested a trans-orientation between them. Furthermore, NOESY correlations (Figure 2) between H-6 and H-9b, H-7 and H-9a, Me-14 and H-9a, H-6 and H-10 led to a suggestion of 1 with either a cubenol (4) or epicubenol (5) skeleton. Notably, the ${ }^{13}$ CNMR data of $\mathbf{1}$ (Table 1) are identical with those reported for pubinernoid $\mathrm{C}(\mathbf{6})$, an epi-cubenol type terpene isolated from the plant Schisandra pubescens var. pubinervis. ${ }^{[19]}$ Interestingly, this microbial 11-hydroxy-epicubenol (1) $\left([\alpha]_{D}^{23}+40.7, \mathrm{MeOH}\right)$ appeared to be an enantiomer of the plant product pubinernoid $\mathrm{C}\left([\alpha]_{D}^{19}-60.7, \mathrm{MeOH}\right)$ deduced from the optical rotation. ${ }^{[19]}$

Compound 2 appears to be a second new epi-cubenol. The molecular formula of compound 2 was proposed to be $\mathrm{C}_{15} \mathrm{H}_{26} \mathrm{O}_{2}\left(\mathrm{~m} / \mathrm{z}[\mathrm{M}+\mathrm{H}]^{+} 239.2006, \Delta-0.2 \mathrm{ppm}\right)$. Comparison of NMR spectral data (Table 1) indicated that compound 2 shares the same epi-cubenol skeleton as $\mathbf{1}$. For example, the chemical shifts of C-1, C-6 and C-14 were conserved between 1 and 2. The large coupling constant $(11.3 \mathrm{~Hz})$ between H-6 and H-7 indicates a transorientation as in $\mathbf{1}$. However, in the ${ }^{1} \mathrm{H}$ NMR spectrum one methyl singlet is absent, instead signals of one oxygen-bonding methylene $(\mathrm{H}-12, \delta 3.83,3.42)$ appeared. The location of this proton at C-13 was inferred from COSY correlations between $\mathrm{H}-11(\delta 1.98), \mathrm{H}-12$ and Me-13 ( $\delta$ 0.94). HMBC correlations (Figure 2$)$ between H-13 and C-7 ( $\delta 47.8), \mathrm{C}-11(\delta 36.1)$ and C$12(\delta 15.8)$ further confirmed this. Thus 2 is confirmed to have a 1,13-dihydroxy-4-cadinene scaffold. Previous reports on two different muurolene isomers revealed distinct ${ }^{13} \mathrm{C}$ NMR data for C-13 ( $\delta 10.7$ ppm for (+)-(1R,3R,6S,7S,11R)-3,12-dihydroxy- $\alpha$-muurolene (7) and $\delta$ 
15.6 ppm for $(+)-(1 \mathrm{R}, 3 \mathrm{R}, 6 \mathrm{~S}, 7 \mathrm{~S}, 11 \mathrm{~S})-3,12$-dihydroxy- $\alpha$-muurolene $(\mathbf{8}) .{ }^{[20]}$ By comparison, the relative configuration at C-7 and C-11 for 2 was established as 7 by ${ }^{13} \mathrm{C}$ NMR data $(\delta 15.8, \mathrm{C}-$ 13) accordingly. An isomer of 2 named as trichapargin A (9) was recently reported from the mushroom Trichaptum pargamenum. ${ }^{[21]}$ Here we name 2 as (+)-12-hydroxy-epicubenol.

Cubenols are a group of cadinene sesquiterpenes reported from cubeb pepper oil. ${ }^{[22]}$ Among the first reports of bacterial volatiles, e.g. geosmin from Actinobacteria, Geber reported epicubenol as a sweet-spicy volatile terpene from bacteria. ${ }^{[23]}$ Recently, heterologous expression of an (+)-epicubenol synthase in Streptomyces sp. led to the production of the bacterial (+)-epicubenol. ${ }^{[24]}$ Here we report two new epicubenol alcohol derivatives (+)-11-hydroxy-epicubenol (1), and (+)-12-hydroxy-epicubenol (2), from a wild bacterial strain.

Compound $\mathbf{3}$ was obtained as another terpene belonging to the cadinane family. In the ${ }^{1} \mathrm{H}$ NMR spectrum, no olefinic proton signals were observed. MS and NMR data of $\mathbf{3}$ (Table 1, Figure 2) showed that this compound resembled the cycloether 5,11-epoxy-10-cadinanol, which was first isolated from the liverwort Ptychanthus striatus. ${ }^{[25]}$ To rigorously elucidate the absolute configurations of $\mathbf{3}$, we grew crystals of this compound and subjected them to $\mathrm{x}-$ ray crystallography. The crystal structure (Figure 3) confirmed the architecture and absolute configuration of $\mathbf{3}$. We found that 3 exhibits also a positive optical rotation $\left([\alpha]_{D}^{23}+16.8\right.$, $\mathrm{MeOH})$, confirming the same absolute configuration as reported for the plant metabolite. ${ }^{[21]}$ Although we have not noticed any pronounced antimicrobial or cytotoxic activities in a preliminary whole-cell screening of the cadinanes, it has been reported that the major metabolite (3) formed through this pathway is cytotoxic. ${ }^{[26]}$

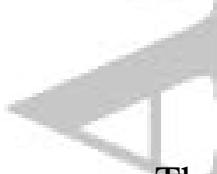

The co-occurrence of the three sesquiterpenes in the mangrove endophyte suggests that 1-3 share a common biosynthetic pathway (Scheme 1). A plausible precursor of all 
congeners would be the 10-carbon ring-containing cis-germacradienyl cation. Since the double bonds in the cis-germacradienyl cation are unfavourably placed for a cyclization reaction, a 1,3-hydride shift would generate a new cadinyl cation, and subsequent deprotonation would yield $\delta$-cadinene. ${ }^{[27]}$ Regiodivergent oxygenation and cyclization would lead to the formation of compounds $\mathbf{1}-\mathbf{3}$.

The bacterial biosynthesis of the plant-derived natural products $\mathbf{1}$ and $\mathbf{3}$ is intriguing and they are important additions to the currently known metabolic potential of endophytes. ${ }^{[28]}$ Cadinane sesquiterpenoids have been reported as metabolites of Phomopsis cassiae, an endophytic fungus associated with Cassia spectabilis. ${ }^{[29]}$ It is particularly remarkable that 5,11-epoxy-10-cadinanol (3) has also been isolated from Perenniporia tephropora, a fungal endophyte from Taxus chinensis var. mairei. ${ }^{[26]}$ Only recently, the same compound was detected as a metabolite of Streptomyces anulatus isolated from Giraffa camelopardalis feces. ${ }^{[30]}$

\section{CONCLUSIONS}

In conclusion, we have reported the isolation of three cadinanes from a mangrove endophyte, two of which have previously been reported as plant metabolites. Consequently, two cadinane structures are new (1 and 2). Furthermore, we show the crystal structure of $\mathbf{3}$ and thus corroborate the proposed structure. Together with recently published, related studies our findings demonstrate that plant-associated microbes represent a potential source of cadinanes originally isolated from plants. Thus, endophytes may be harnessed for the production of valuable cadinane-derived pharmaceuticals by fermentation. From an ecological point of view, the discovery of cadinane-producing endophytes is intriguing 
because endophytes might, at least in part, account to the production of terpenoid volatiles that could play roles in plants communication, and cytotoxic compounds like $\mathbf{3}$ could contribute to the defensive armory against herbivores.

\section{EXPERIMENTAL}

General IR spectra were recorded on a Bruker FT-IR (IFS 55) spectrometer. UV spectra were recorded on a Cary 1 Bio UV-visible spectrophotometer (Variant). Optical rotation was recorded on a Propol digital automatic polarimeter (Dr. Wolfgang Kernchen GmbH, Seelze, Germany). EI spectra were recorded on SSQ 710 (manufacured by Finnigan MAT). CI spectra were measured on Thermo Q-Exactive GC coupled to a GC-Chromatography. Open column chromatography was performed on silica gel 60 (Merck, $0.04-0.063 \mathrm{~mm}, 230-400$ mesh ASTM) and Sephadex LH-20 (Pharmacia). TLC analysis was performed on silica gel plates (Sil G/UV254, $0.20 \mathrm{~mm}$, Macherey-Nagel). Preparative HPLC was performed on a Waters HPLC system using a Nucleosil $100-5 \mathrm{C}_{18}$ column $(5 \mu \mathrm{m}, 250$ x $16 \mathrm{~mm})$ with a UV detector. The NMR spectra were recorded on Bruker Avance DRX 500 and 600 NMR spectrometers equipped with $5 \mathrm{~mm}$ probes, at $300 \mathrm{~K}$. Samples of 1 (1.4 mg), 2 (4.3 mg), 3 (7.9 mg) were each dissolved in $0.5 \mathrm{ml}$ of $\mathrm{CDCl}_{3}$ and transferred into a $5 \mathrm{~mm} \mathrm{NMR}$ tube. The ${ }^{1} \mathrm{H},{ }^{13} \mathrm{C}$ NMR (at 500 and $125 \mathrm{MHz}$, respectively) were measured for compounds $\mathbf{1}$ and 2. Meanwhile, ${ }^{1} \mathrm{H}$, and ${ }^{13} \mathrm{C}$ NMR spectra for compound 3 were measured at $600 \mathrm{MHz}$ and 150 $\mathrm{MHz}$, respectively. Chemical shifts are given on the $\delta$ scale and referenced to $\mathrm{CDCl}_{3}$ at 7.24 ppm for proton and 77.38 ppm for carbon. Coupling constants $(J)$ are in Hertz. For the 2D experiments, including COSY, HSQC, HMBC, and NOESY, all data were acquired with $2048 \times 128(\mathrm{t} 2 \times \mathrm{t} 1), 1024 \times 192(\mathrm{t} 2 \times \mathrm{t} 1), 2048 \times 192(\mathrm{t} 2 \times \mathrm{t} 1)$, and $2048 \times 192(\mathrm{t} 2 \times \mathrm{t} 1)$ data points, respectively. The HMBC experiment used a long-range coupling constant of $10 \mathrm{~Hz}$.

Compound 1: for ${ }^{1} \mathrm{H}$ NMR experiment, pulse sequence zg30, 128 transients were acquired with a $1 \mathrm{~s}$ relaxation delay using 65536 data points. The $90^{\circ}$ pulse duration was $14 \mu$ s, and the 
spectral width was $10000.000 \mathrm{~Hz}$. Data matrix size after Fourier transformation was 131072. The ${ }^{13} \mathrm{C}$ NMR spectrum pulse sequence udeft were obtained with a spectral width of $29761.904 \mathrm{~Hz}$ using 19996 data points. The $90^{\circ}$ pulse duration was $13 \mu \mathrm{s}$. The HSQC spectrum was recorded with ${ }^{1} J(\mathrm{CH})=140 \mathrm{~Hz}$. The NOESY mixing time was $1.5 \mathrm{~s}$.

Compound 2: for ${ }^{1} \mathrm{H}$ NMR experiment, pulse sequence zg30, 128 transients were acquired with a $1 \mathrm{~s}$ relaxation delay using 65536 data points. The $90^{\circ}$ pulse duration was $14 \mu \mathrm{s}$, and the spectral width was $10000.000 \mathrm{~Hz}$. Data matrix size after Fourier transformation was 131072. The ${ }^{13} \mathrm{C}$ NMR spectrum pulse sequence udeft was obtained with a spectral width of $29761.904 \mathrm{~Hz}$ using 65536 data points, the spectral width $29761.904 \mathrm{~Hz}$. The HSQC spectrum was recorded with ${ }^{1} J(\mathrm{CH})=140 \mathrm{~Hz}$. The NOESY mixing time was $1.2 \mathrm{~s}$.

Compound 3: for ${ }^{1} \mathrm{H}$ NMR experiment, pulse sequence zg30, 64 transients were acquired with a $1 \mathrm{~s}$ relaxation delay using 65536 data points. The $90^{\circ}$ pulse duration was $8 \mu \mathrm{s}$, and the spectral width was $12019.230 \mathrm{~Hz}$. Data matrix size after Fourier transformation was 262144. The ${ }^{13} \mathrm{C}$ NMR spectrum pulse sequence zgpg30, obtained with a spectral width of 36231.883 Hz using 65536 data points; The HSQC spectrum was recorded with ${ }^{1} J(\mathrm{CH})=145 \mathrm{~Hz}$; The NOESY mixing time was $1.5 \mathrm{~s}$.

Strain Isolation and Taxonomic Classification. JMRC:ST027706 was isolated from the stems of Bruguiera gymnorrhiza. Isolation and taxonomy can be found in the previous report. ${ }^{[16]}$ The bacterium is stored at Hans-Knoell Institute.

\section{Extraction and Isolation}

The broth of a 200 L fermentation of Streptomyces sp. JMRC:ST027706, an endophyte isolated from stems of Bruguiera gymnorrhiza, ${ }^{[16]}$ was filtered and loaded onto an Amberchrom 161c resin LC column $(200 \times 20 \mathrm{~cm}, 6 \mathrm{~L})$. Elution with a linear gradient of $\mathrm{H}_{2} \mathrm{O} / \mathrm{CH}_{3} \mathrm{OH}$ (from $30 \%$ to $100 \% \mathrm{v} / \mathrm{v}$, flow rate $0.5 \mathrm{~L} \mathrm{~min}^{-1}$, in $58 \mathrm{~min}$ ) afforded seven 
fractions (F1-F7). F1-F5 were combined and extracted by ethyl acetate and evaporated to afford the extract $(8 \mathrm{~g})$. It was firstly fractionated by silica gel column chromatography with a $\mathrm{CH}_{2} \mathrm{Cl}_{2} / \mathrm{CH}_{3} \mathrm{OH}$ gradient to yield four fractions, A-D. Fraction A was firstly fractionated by a Sephadex $\mathrm{LH}-20\left(\mathrm{CH}_{2} \mathrm{Cl}_{2} / 50 \% \mathrm{CH}_{3} \mathrm{OH}\right)$ column, and six fractions (A1-A6) were obtained.

Fraction A1 was further separated by a RP- $\mathrm{C}_{18}$ column $\left(\mathrm{CH}_{3} \mathrm{OH} / \mathrm{H}_{2} \mathrm{O}\right.$ as gradient $)$ to afford seventeen FA1-A1 to FA1-A23. FA1-A15 were separated by silica gel column chromatography $\left(\mathrm{CH}_{2} \mathrm{Cl}_{2} / \mathrm{CH}_{3} \mathrm{OH}\right.$ as gradient) to afford $\mathbf{3}(7.9 \mathrm{mg})$. FA1-A16 was separated by silica gel column chromatography $\left(\mathrm{CH}_{2} \mathrm{Cl}_{2} / \mathrm{CH}_{3} \mathrm{OH}\right.$ as gradient) to afford $\mathbf{1}(1.4 \mathrm{mg})$. FA1-A17 was separated by silica gel column chromatography $\left(\mathrm{CH}_{2} \mathrm{Cl}_{2} / \mathrm{CH}_{3} \mathrm{OH}\right.$ as gradient $)$ to afford 2 (4.3 $\mathrm{mg})$.

(+)-11-Hydroxy-epicubenol (1): colorless solid; $[\alpha]_{D}^{23} 40.7$ (c 0.44, MeOH); IR (film) $v_{\max }$ $3433.9,2915.3,1699.3,1652.8,1558.4,1540.6,1506.8,1456.9,1373.6,1283.1,1153.6$, 1081.1, 1023.1, 965.1, 925.0, 890.2, 854.2, 791.7, 668.4, 629.2 $\mathrm{cm}^{-1}$; EIMS (14 eV) $\mathrm{m} / \mathrm{z}: 238$, 220, 205, 202, 194, 187, 177, 174, 163, 159, 147, 132, 120, 106, 94, 59, 32; HRCIMS m/z [M $+\mathrm{H}]^{+} 239.2006$ (calculated for $\mathrm{C}_{15} \mathrm{H}_{27} \mathrm{O}_{2}, 239.2006, \Delta 0.2 \mathrm{ppm}$ ); NMR data see Table 1 .

(+)-12-Hydroxy-epicubenol (2): colorless solid; $[\alpha]_{D}^{23} 0.4$ (c $\left.0.04, \mathrm{MeOH}\right)$; EIMS $(14 \mathrm{eV})$ : 238, 221, 205, 190, 179, 170, 159, 149, 147, 134, 119, 110, 92, 85, 81, 32; HRCIMS: [M + $\mathrm{H}]^{+} 239.2006$ (calculated for $\mathrm{C}_{15} \mathrm{H}_{27} \mathrm{O}_{2}, 239.2006, \Delta 0.2 \mathrm{ppm}$ ); NMR data see Table 1 .

5,11-Epoxy-10-cadinanol (3): colorless solid; $[\alpha]_{D}^{23} 16.8$ (c $\left.0.38, \mathrm{MeOH}\right)$; IR (film) $v_{\max }$ $3407.1,2922.3,1716.3,1453.9,1375.5,1363.5,1317.8,1253.4,1191.6,1162.5,1142.6$, $1127.3,1100.1,1081.6,1055.6,1019.3,1100.1,1081.6,1055.6,1019.3,1000.6,980.4$, 
938.0, 915.6, 875.7, 836.7, 794.7, 767.0, 751.7, 649.8, $636.5 \mathrm{~cm}^{-1}$; EIMS (14 eV) m/z: 238, 223, 212, 205, 196, 180, 162, 147, 137, 122, 106, 95, 32; NMR data see Table 1.

\section{Cytotoxicity Assays}

A modified propidium iodide assay was used to determine the cytotoxic activities of compounds 2 and 3 against 12 cell lines derived from solid human tumors. The test procedure has been described elsewhere. ${ }^{[31]}$ Cell lines tested were derived from patient tumors engrafted as a subcutaneously growing tumor in NMRI nu/nu mice or obtained from the American Type Culture Collection (Rockville, MD, USA), National Cancer Institute (Bethesda, MD, USA), or Deutsche Sammlung von Mikroorganismen and Zellkulturen (Braunschweig, Germany). Inhibitory concentrations are provided as 50\% inhibition of cell growth (absolute $\mathrm{IC}_{50}$, determined by two-point-curve- fit after plotting compound concentration versus fluorescence intensity). Neither $\mathbf{2}$ nor $\mathbf{3}$ exhibited cytotoxic activities $\left(\mathrm{IC}_{50}>30 \mu \mathrm{M}\right)$.

\section{Crystal Structure Determination}

The intensity data were collected on a Nonius KappaCCD diffractometer, using graphitemonochromated Mo- $\mathrm{K}_{\alpha}$ radiation. Data were corrected for Lorentz and polarization effects; absorption was taken into account on a semi-empirical basis using multiple-scans. ${ }^{[32]}$

The structure was solved by direct methods (SHELXS) and refined by full-matrix least squares techniques against $\mathrm{Fo}^{2}$ (SHELXL-2018). ${ }^{[33]}$ The hydrogen atom bonded to hydroxy-group O1 were located by difference Fourier synthesis and refined isotropically. All other hydrogen atoms were included at calculated positions with fixed thermal parameters.

The analysis of the absolute structure using likelihood methods ${ }^{[34]}$ was performed using PLATON. ${ }^{[35]}$ The method calculated that the probability that the structure is inverted is smaller than $1 \times 10^{-4}$. The resulting value was $y=0.0(2)$ indicating that the absolute structure has probably been determined correctly. The absolute structural parameter for the standard uncertainty using the Flack-parameter ${ }^{[36]}$ is $0.0(3)$.

XP (SIEMENS Analytical X-ray Instruments, Inc.) was used for structure representations. 
Crystal Data for 3: $\mathrm{C}_{15} \mathrm{H}_{26} \mathrm{O}_{2}, \mathrm{Mr}=238.36$ gmol $^{-1}$, colourless prism, size $0.125 \times 0.110 \times 0.090$ $\mathrm{mm}^{3}$, orthorhombic, space group P $22_{1} 2_{1} 2_{1}, \mathrm{a}=8.3614(1), \mathrm{b}=11.1955(1), \mathrm{c}=14.8478(2) \AA$, V $=1389.90(3) \AA^{3}, \mathrm{~T}=-140{ }^{\circ} \mathrm{C}, \mathrm{Z}=4, \rho_{\text {calcd. }}=1.139 \mathrm{~g} \mathrm{~cm}^{-3}, \mu\left(\mathrm{Mo}-\mathrm{K}_{\alpha}\right)=0.73 \mathrm{~cm}^{-1}$, multi-scan, transmin: 0.6079, transmax: 0.7456, $\mathrm{F}(000)=528,12472$ reflections in $\mathrm{h}(-10 / 10), \mathrm{k}(-14 / 14)$, $1(-19 / 19)$, measured in the range $2.744^{\circ} \leq \Theta \leq 27.487^{\circ}$, completeness $\Theta_{\max }=99.7 \%, 3189$ independent reflections, $R_{\text {int }}=0.0311,3084$ reflections with $F_{o}>4 \sigma\left(F_{o}\right), 162$ parameters, 0 restraints, $\mathrm{R} 1_{\mathrm{obs}}=0.0309, \mathrm{wR}^{2}{ }_{\mathrm{obs}}=0.0846, \mathrm{R} 1_{\text {all }}=0.0322, \mathrm{wR}_{\text {all }}^{2}=0.0858, \mathrm{GOOF}=1.079$, largest difference peak and hole: $0.247 /-0.144 \mathrm{e} \AA^{-3}$.

\section{Data Deposition}

Crystallographic data deposited at the Cambridge Crystallographic Data Centre under CCDC1406841 for 3 contain the supplementary crystallographic data excluding structure factors; this data can be obtained free of charge via www.ccdc.cam.ac.uk/conts/retrieving.html (or from the

Cambridge Crystallographic Data Centre, 12, Union Road, Cambridge CB2 1EZ, UK; fax: (+44) 1223-336-033; or deposit@ccdc.cam.ac.uk).

\section{Supplemental Material}

Experimental details, details on x-ray crystallography, NMR data and spectra of compounds 1-3. The raw NMR data ((FIDs) can be downloaded at https://files.dtu.dk/u/rg_qTOAP6ma8D-pN/NMR\%20data\%20files.zip 


\section{Acknowledgements}

We thank A. Perner and F. Rhein for MS and NMR measurements, respectively, H. Heinecke and U. Valentin for sample preparation and HPLC, C. Heiden and M. Steinacker for fermentation and downstream processing, Dr. N. Ueberschaar for GC-Obitrap measurements, Dr.

M. Wibowo for proof-reading the manuscript. This research was supported by the BMBF (Intercommunicate).

Author Contribution Statement. Ling Ding and Helmar Görls performed the experiments, analyzed the data. Ling Ding, Christian Hertweck and Helmar Görls wrote the article. 


\section{References}

[1] a)F. Van Opstaele, T. Praet, G. Aerts, L. De Cooman, J. Agric. Food Chem. 2013, 61, 10555; b)F. Sefidkon, S. Salehyar, M. Mirza, M. Dabiri, Flavour Frag. J. 2004, 19, 579.

[2] X. Tian, J. X. Ruan, J. Q. Huang, C. Q. Yang, X. Fang, Z. W. Chen, H. Hong, L. J. Wang, Y. B. Mao, S. Lu, T. Z. Zhang, X. Y. Chen, Proc. Natl. Acad. Sci. 2018, 115, E5410.

[3] R. Rojas, B. Bustamante, P. Ventosilla, I. Fernadez, L. Caviedes, R. H. Gilman, O. Lock, G. B. Hammond, Chem. Pharm. Bull. 2006, 54, 278.

[4] K. He, L. Zeng, G. Shi, G. X. Zhao, J. F. Kozlowski, J. L. McLaughlin, J. Nat. Prod. 1997, 60, 38.

[5] L. He, J. Hou, M. Gan, J. Shi, S. Chantrapromma, H. K. Fun, I. D. Williams, H. H. Sung, J. Nat. Prod. 2008, 71, 1485.

[6] B. K. Datta, M. Mukhlesur Rahman, A. I. Gray, L. Nahar, S. A. Hossein, A. A. Auzi, S. D. Sarker, J. Nat. Med. 2007, 61, 391.

[7] Y. Tu, Angew. Chem. Int. Ed. Engl. 2016, 55, 10210.

[8] C. J. Paddon, J. D. Keasling, Nat. Rev. Microbiol. 2014, 12, 355.

[9] M. D. Leavell, D. J. McPhee, C. J. Paddon, Curr. Opin. Biotechnol. 2016, 37, 114.

[10] I. Burkhardt, N. B. Kreuzenbeck, C. Beemelmanns, J. S. Dickschat, Org. Biomol. Chem. 2019, 17, 3348 .

[11] P. Rabe, T. Schmitz, J. S. Dickschat, Beilstein J. Org. Chem. 2016, 12, 1839.

[12] F. C. Pollak, R. G. Berger, Appl. Environ. Microbiol. 1996, 62, 1295.

[13] Y. Hu, W. K. Chou, R. Hopson, D. E. Cane, Chem. Biol. 2011, 18, 32.

[14] L. Ding, R. Pfoh, S. Ruhl, S. Qin, H. Laatsch, J. Nat. Prod. 2009, 72, 99.

[15] a) L. Ding, H. M. Dahse, C. Hertweck, J. Nat. Prod. 2012, 75, 617; b) L. Ding, L, A. Maier, H. H. Fiebig, H. Gorls, W. H. Lin, G. Peschel, C. Hertweck, Angew. Chem. Int. Ed. 2011, 50, 1630; c) L. Ding, J. Franke, C. Hertweck, Org. Biomol. Chem. 2015, 13, 1618; d) L. Ding, G. Peschel, C. Hertweck, ChemBioChem 2012, 13, 2661.

[16] L. Ding, H. Goerls, K. Dornblut, W. Lin, A. Maier, H. H. Fiebig, C. Hertweck, J. Nat. Prod. 2015, 78, 2963.

[17] L. Ding, A. Maier, H. H. Fiebig, W. H. Lin, G. Peschel, C. Hertweck, J. Nat. Prod. 2012, 75, 2223.

[18] a) L. Ding, A. Maier, H. H. Fiebig, W. H. Lin, C. Hertweck, Org Biomol Chem 2011, 9, 4029; b) L. Ding, J. Munch, H. Goerls, A. Maier, H. H. Fiebig, W. H. Lin, C. Hertweck, Bioorg Med Chem Lett 2010, 20, 6685; c) Z. Xu, M. Baunach, L. Ding, C. Hertweck, Angew. 
Chem. Int. Ed. 2012, 51, 10293; d) M. Baunach, L. Ding, K. Willing, C. Hertweck, Angew. Chem. Int. Ed. 2015, 54, 13279.

[19] S. X. Huang, J. Yang, W. L. Xiao, Y. L. Zhu, R. T. Li, L. M. Li, J. X. Pu, X. Li, S. H. Li, H. D. Sun, Helvetica 2006, 89, 1169.

[20] X. Y. Yang, J. H. Ding, T. Feng, Z. H. Li, Y. Li, G. Q. Wang, S. H. He, J. K. Liu, Phytochemistry. 2014, 104, 89.

[21] B. Tang, X. Du, H. A. Long, J. Du, J. M. Guo, X. Hu, H. Tu, L. Yang, H. J. Liu, Nat. Prod. Res. 2017, 31, 2454.

[22] Y. Ohta, Y, Hirose, Tetrahedron Lett. 1967, 8, 2073.

[23] N. N. Geber, Phytochemistry 1971, 10, 185.

[24] C. Nakano, T. Tezuka, S. Horinouchi, Y. Ohnishi, J. Antibiot. 2012, 65, 551.

[25] T. Hashimoto, S. Takaoka, M. Tanaka, Y. Asakawa, Heterocycles 2003, 59, 645.

[26] L. S. Wu, C. L. Hu, T. Han, Z. Cheng, X. Q. Ma, K. Rahman, L. P. Qin, Appl. Microbiol. Biotechnol. 2012, 97, 305.

[27] P. M. Dewick, 2009. Medicinal Natural Products, a Biosynthetic Approach, Third Edition, p 212. Wiley India Pvt.Ltd.

[28] S. Kusari, C. Hertweck, M. Spiteller, Chem. Biol. 2012, 19, 792.

[29] G. H. Silva, H. L. Teles, L. M. Zanardi, M. C. Marx Young, M. N. Eberlin, R. Hadad, L. H. Pfenning, C. M. Costa-Neto, I. Castro-Gamboa, V. da Silva Bolzani, A. R. Araujo, Phytochemistry 2006, 67, 1964.

[30] N. Ding, L. Han, Y. Jiang, G. Li, J. Liu, Y. Mu, X. Huang, Magn. Reson. Chem. 2018, 56,352 .

[31] W. A. Dengler, J. Schulte, D. P. Berger, R. Mertelsmann, H. H. Fiebig, Anticancer Drugs 1995, 6, 522.

[32] a) B. V. Nonius, 1998. COLLECT, Data Collection Software; Netherlands; b) Z. Otwinowski, W. Minor, 1997. Processing of X-Ray Diffraction Data Collected in Oscillation Mode“, in Methods in Enzymology, Vol. 276, Macromolecular Crystallography, Part A, edited by Carter CW \& Sweet RM, pp. 307-326, Academic Press, San Diego, USA; c)W. I. Madison, SADABS 2.10, Bruker-AXS inc., 2002, U.S.A

[33] G. M. Sheldrick, Crystal Structure Refinement with SHELXL. Acta Cryst. 2015, C71, 3. [34] R. W. W. Hooft, L. H. Straver, A. L. Spek, Determination of absolute structure using Bayesian statistics on Bijvoet differences. J Appl Cryst. 2008, 41, 96.

[35] A. L. Spek, PLATON SQUEEZE: a tool for the calculation of the disordered solvent contribution to the calculated structure factors. Acta Cryst. 2015. C71, 9. 
[36] H. D. Flack, G. Bernardinelli, J Appl Cryst. 2000, 33, 1143.

Table 1. NMR data for compounds 1-4.

\begin{tabular}{|c|c|c|c|c|c|c|c|}
\hline Position & \multicolumn{2}{|l|}{1} & \multirow{2}{*}{$\begin{array}{c}\mathbf{4}^{19} \\
\delta_{\mathrm{C}}, \text { type }\end{array}$} & \multicolumn{2}{|l|}{2} & \multicolumn{2}{|c|}{3} \\
\hline & $\delta_{\mathrm{H}}(J$ in $\mathrm{Hz})$ & $\begin{array}{l}\delta_{\mathrm{C}}, \\
\text { type }\end{array}$ & & $\delta_{\mathrm{H}}(J$ in $\mathrm{Hz})$ & $\delta_{\mathrm{C}}$, type & $\delta_{\mathrm{H}}(J$ in $\mathrm{Hz})$ & $\delta_{\mathrm{C}}$, type \\
\hline & - & 72.7, C & $72.7, \mathrm{C}$ & - & 72.6, C & $\begin{array}{c}1.31 \\
\text { (overlapping } \\
\text { ) }\end{array}$ & $49.1, \mathrm{CH}$ \\
\hline 2 & $\begin{array}{c}1.69 \\
\text { (overlapping), } \\
1.58 \\
\text { (overlapping) }\end{array}$ & $\begin{array}{l}21.8, \\
\mathrm{CH}_{2}\end{array}$ & $21.9, \mathrm{CH}_{2}$ & $\begin{array}{c}1.62 \\
\text { (overlapping) }\end{array}$ & $21.8, \mathrm{CH}_{2}$ & $\begin{array}{c}1.51(\mathrm{~m}), \\
1.19 \\
\text { (overlapping } \\
\text { ) }\end{array}$ & $19.1, \mathrm{CH}_{2}$ \\
\hline & $\begin{array}{c}2.08 \\
\text { (overlapping) }\end{array}$ & $\begin{array}{l}26.6, \\
\mathrm{CH}_{2}\end{array}$ & $26.6, \mathrm{CH}_{2}$ & $2.12(\mathrm{t}, 8.6)$ & $26.6, \mathrm{CH}_{2}$ & $\begin{array}{l}1.64(\mathrm{~m}), \\
1.42(\mathrm{~m})\end{array}$ & $30.1, \mathrm{CH}_{2}$ \\
\hline & - & $\begin{array}{c}136.4 \\
\mathrm{C}\end{array}$ & $136.3, \mathrm{C}$ & - & $134.4, \mathrm{C}$ & $2.18(\mathrm{~m})$ & $30.6, \mathrm{CH}$ \\
\hline & $\begin{array}{c}5.63(\mathrm{dq}, J 5,7 \\
=1.6, J 5,6= \\
6.1)\end{array}$ & $\begin{array}{c}122.4, \\
\mathrm{CH}\end{array}$ & $122.5, \mathrm{CH}$ & $\begin{array}{c}5.50(\mathrm{dq}, J 5,7 \\
=1.6, J 5,6= \\
5.3)\end{array}$ & $122.1, \mathrm{CH}$ & $\begin{array}{c}3.43(\mathrm{dd}, \\
J 5,6=10.5, \\
J 4,5=5.0)\end{array}$ & $81.5, \mathrm{CH}$ \\
\hline 6 & $\begin{array}{c}1.84(\mathrm{dd}, J 6,7 \\
=11.1, J 5,6= \\
6.1)\end{array}$ & $\begin{array}{c}47.9, \\
\mathrm{CH}\end{array}$ & $48.0, \mathrm{CH}$ & $\begin{array}{c}1.79(\mathrm{dd}, J 6,7 \\
=11.3, J 5,6= \\
5.3)\end{array}$ & $47.9, \mathrm{CH}$ & $\begin{array}{c}1.18 \\
\text { (overlapping } \\
\text { ) }\end{array}$ & $43.4, \mathrm{CH}$ \\
\hline 7 & $\begin{array}{c}1.35(\mathrm{ddd} \\
J 7,8 \beta=12.4 \\
J 6,7=11.1 \\
J 7,8 \alpha=3.2)\end{array}$ & $\begin{array}{l}54.9, \\
\mathrm{CH}\end{array}$ & $54.9, \mathrm{CH}$ & $1.25(\mathrm{~m})$ & $47.8, \mathrm{CH}$ & $\begin{array}{c}1.40(\mathrm{dd} \\
J 6,7=12.2 \\
J 7,8 \alpha=3.8)\end{array}$ & $52.8, \mathrm{CH}$ \\
\hline 8 & $\begin{array}{c}1.74(\mathrm{ddd}, \\
J 8 \alpha, 8 \beta \\
=13.0, J 8 \alpha \\
9 \alpha=6.4, J 7 \\
8 \alpha=3.2)\end{array}$ & $\begin{array}{l}28.8, \\
\mathrm{CH}_{2}\end{array}$ & $28.9, \mathrm{CH}_{2}$ & $\begin{array}{c}1.61 \\
\text { (overlapping), } \\
1.08 \\
\text { (overlapping) }\end{array}$ & $26.9, \mathrm{CH}_{2}$ & $\begin{array}{c}1.62(\mathrm{dd}, \\
J 8 \alpha, 8 \beta= \\
6.7, J 7,8 \alpha \\
=3.8 \text { ), } 1.20 \\
\text { (overlapping }\end{array}$ & $23.7, \mathrm{CH}_{2}$ \\
\hline
\end{tabular}




\begin{tabular}{|c|c|c|c|c|c|c|c|}
\hline & $\begin{array}{c}1.04(\mathrm{ddd}, \\
\quad J 8 \alpha, 8 \beta \\
=13.0, J 7,8 \beta \\
=12.4, J 9 \alpha \\
8 \beta=3.2)\end{array}$ & & & & & ) & \\
\hline 9 & $\begin{array}{c}1.61 \\
\text { (overlapping), } \\
1.16 \\
\text { (overlapping) }\end{array}$ & $\begin{array}{l}31.1, \\
\mathrm{CH}_{2}\end{array}$ & $31.1, \mathrm{CH}_{2}$ & $\begin{array}{c}1.58 \\
\text { (overlapping), } \\
1.06 \\
\text { (overlapping) }\end{array}$ & $31.4, \mathrm{CH}_{2}$ & $\begin{array}{c}1.79(\mathrm{dt}, \\
J 9 \alpha, 9 \beta= \\
13.0, J 8 \alpha, 9 \beta \\
=3.2, J 8 \beta, 9 \beta \\
=3.2) ; 1.50 \\
(\mathrm{~m})\end{array}$ & $43.3, \mathrm{CH}_{2}$ \\
\hline 10 & $\begin{array}{c}1.60 \\
\text { (overlapping) }\end{array}$ & $\begin{array}{l}41.5, \\
\mathrm{CH}\end{array}$ & $41.5, \mathrm{CH}$ & $\begin{array}{c}1.60 \\
\text { (overlapping) }\end{array}$ & $41.8, \mathrm{CH}$ & - & 73.1, C \\
\hline 1 & 7 & 74.0, C & 74.0, C & $1.98(\mathrm{~m})$ & $36.1, \mathrm{CH}$ & - & $81.6, \mathrm{C}$ \\
\hline 12 & $1.13(\mathrm{~s})$ & $\begin{array}{l}30.2, \\
\mathrm{CH}_{3}\end{array}$ & $30.2, \mathrm{CH}_{3}$ & $\begin{array}{c}3.42(\mathrm{dd}, \\
J 11,12 \mathrm{~A} \\
=10.3, \\
J 12 \mathrm{~A}, 12 \mathrm{~B}= \\
10.3), 3.83 \\
(\mathrm{dd}, \\
J 12 \mathrm{~A}, 12 \mathrm{~B}= \\
10.3, \mathrm{~J} 11,12 \mathrm{~B} \\
=5.0)\end{array}$ & $65.0, \mathrm{CH}_{2}$ & $1.02(\mathrm{~s})$ & $24.6, \mathrm{CH}_{3}$ \\
\hline 13 & $1.18(\mathrm{~s})$ & $\begin{array}{l}24.7, \\
\mathrm{CH}_{3}\end{array}$ & $24.8, \mathrm{CH}_{3}$ & $\begin{array}{c}0.94(\mathrm{~d} \\
J 11,13=6.4)\end{array}$ & $15.8, \mathrm{CH}_{3}$ & $1.23(\mathrm{~s})$ & $28.9, \mathrm{CH}_{3}$ \\
\hline 14 & $\begin{array}{c}0.94(\mathrm{~d} \\
J 10,14=6.7)\end{array}$ & $\begin{array}{l}15.2 \\
\mathrm{CH}_{3}\end{array}$ & $15.2, \mathrm{CH}_{3}$ & $\begin{array}{c}0.95(\mathrm{~d} \\
J 10,14=6.6)\end{array}$ & $15.1, \mathrm{CH}_{3}$ & $1.17(\mathrm{~s})$ & $21.7, \mathrm{CH}_{3}$ \\
\hline 15 & $\begin{array}{c}1.70 \\
\text { (overlapping) }\end{array}$ & $\begin{array}{l}23.4, \\
\mathrm{CH}_{3}\end{array}$ & $23.4, \mathrm{CH}_{3}$ & $1.69(\mathrm{~s})$ & $23.5, \mathrm{CH}_{3}$ & $\begin{array}{c}0.87(\mathrm{~d}, J 4 \\
15=7.0)\end{array}$ & $10.6, \mathrm{CH}_{3}$ \\
\hline
\end{tabular}


Figures

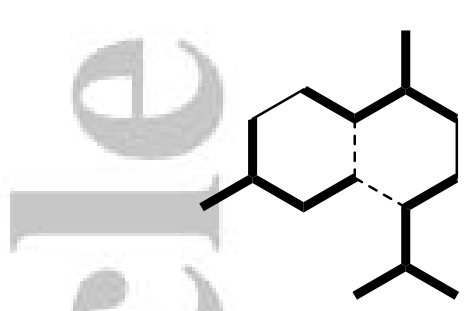

Cadinane

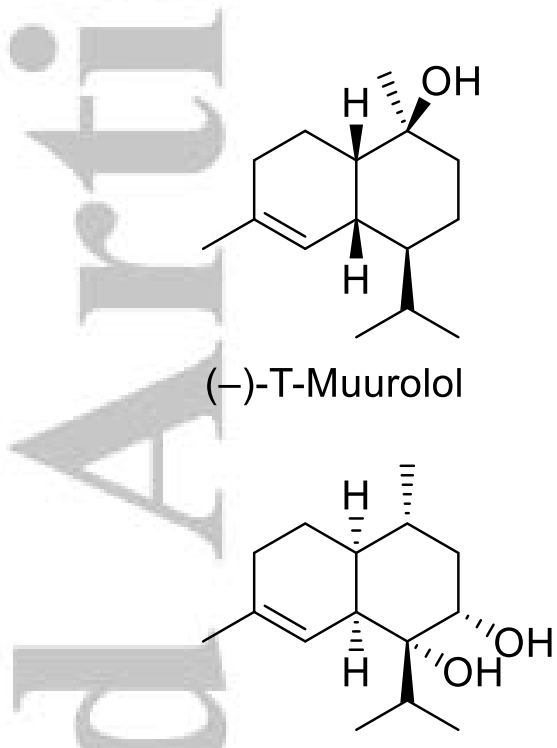

Cadinan-3-ene6,7-diol<smiles>C=C1CC[C@H](C(C)C)[C@]2(C)C=C(C)CC[C@@H]12</smiles>

$\gamma$-Cadinene<smiles>C=C(C)[C@H]1CC[C@@H](O)[C@H]2CCC(C)=C[C@H]12</smiles>

T-Cadinol<smiles>CC1=C[C@H]2[C@@H](C(=O)O)CCC(C(C)C)[C@H]2CC1</smiles>

Polygosumic acid<smiles>CC1=C[C@H]2C(=C(C)CC[C@@H]2C(C)C)CC1</smiles>

$(+)$ - $\delta$-Cadinene<smiles>C=C(C)[C@H]1CC[C@@H](O)[C@H]2CCC(C)=C[C@H]12</smiles>

$\alpha$-Cadinol<smiles>C=C(C(=O)O)[C@H]1CC[C@@H](C)[C@H]2CCC(C)=C[C@H]12</smiles>

Artemisinic acid

Figure 1. Structures of representative cadinanes. 

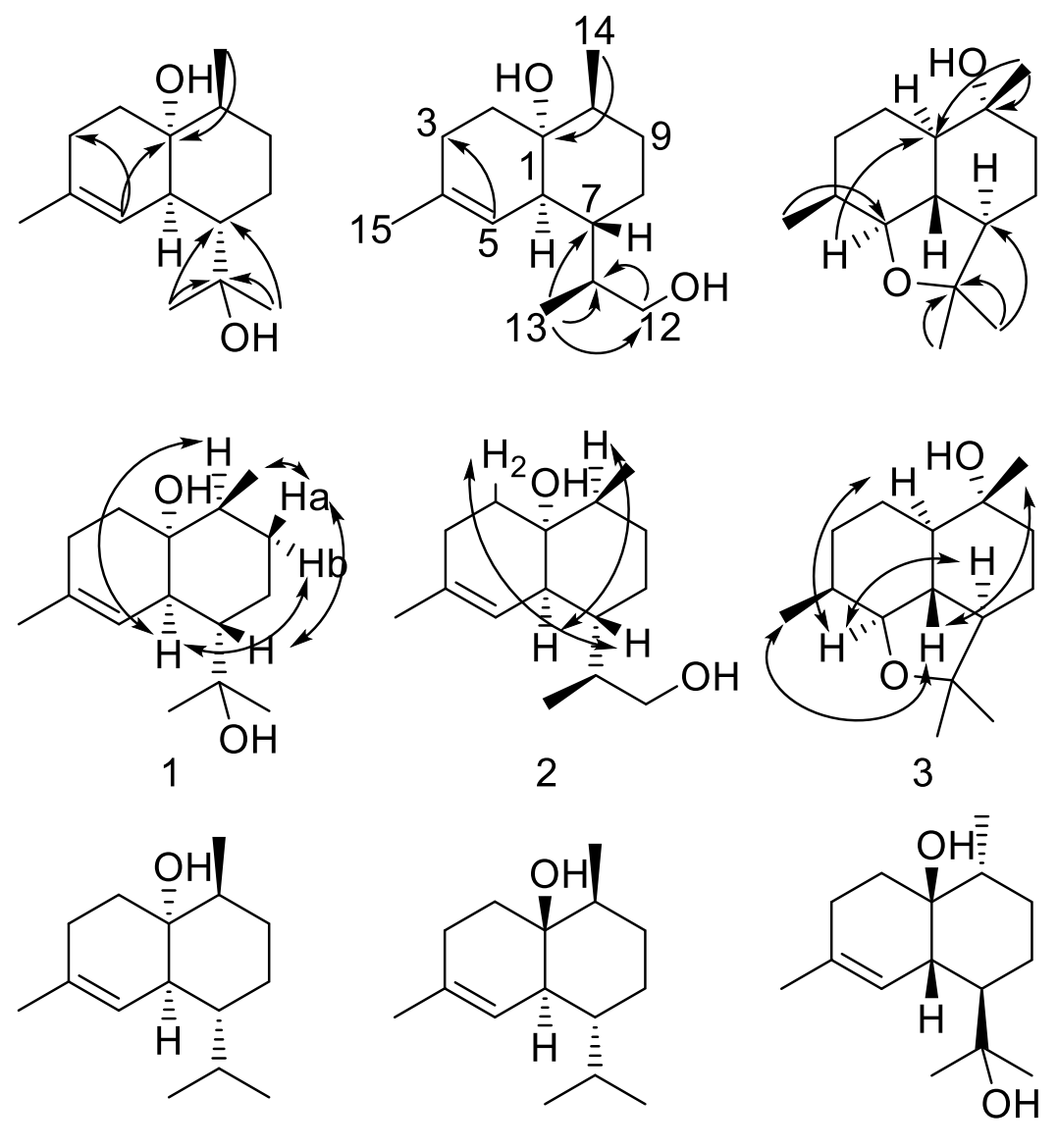

4

5

6<smiles>CC1=C[C@]2([C@@H](C)CO)CC=C(C)[C@@H]2C[C@@H]1O</smiles>

7<smiles>CC1=C[C@]2([C@@H](C)CO)CC[C@H](C)C2CC[C@@H]1O</smiles>

8<smiles>CC1=C[C@H]2[C@@H]([C@H](C)CO)CC[C@@H](C)[C@]2(O)CC1</smiles>

9

Figure 2. Structures of cadinane-type sesquiterpenes (1-3) isolated in this work, (+)-cubenol (4), (+)-epicubenol (5), Schisandra metabolite pubinernoid C (6), and of basidiomycetederived metabolites (7-9). Selected HMBC (single arrows) and NOESY correlations (double arrows) are indicated. 


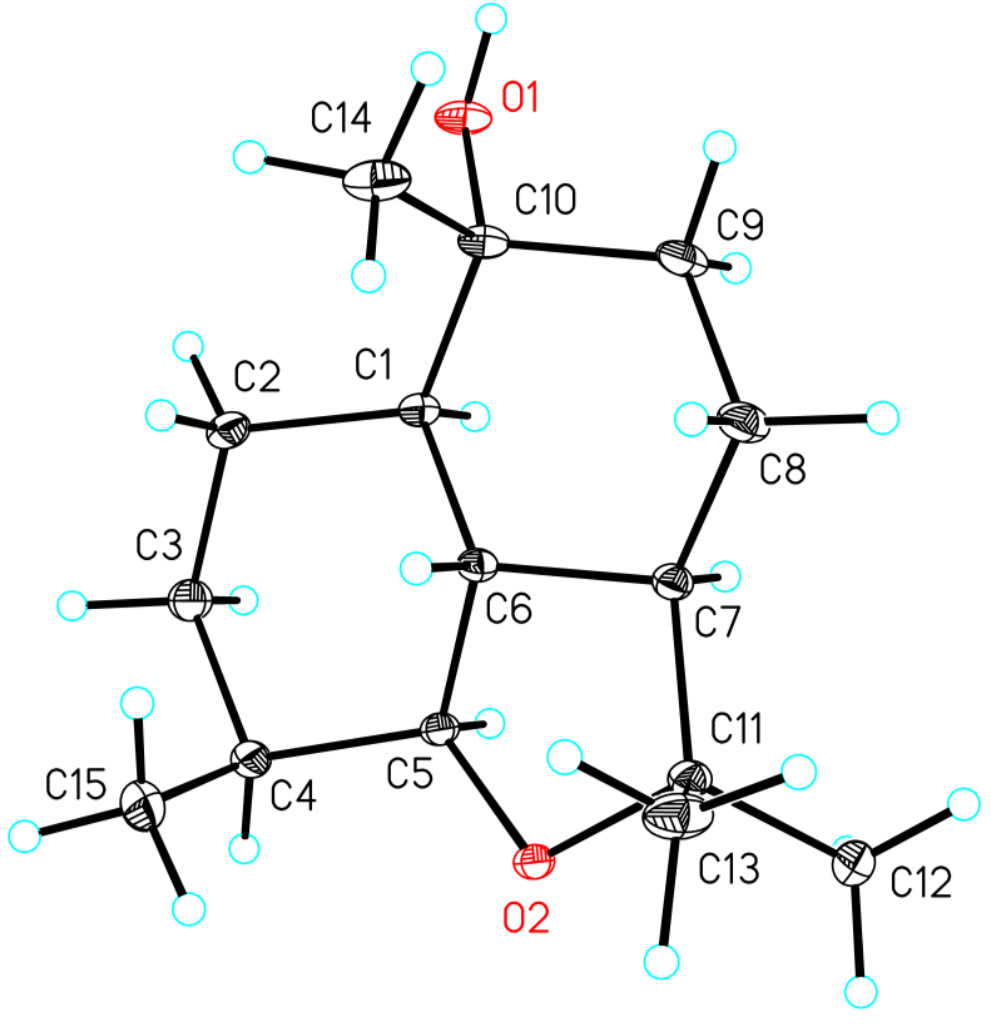

Figure 3. ORTEP drawing of crystal structure for 3 . 


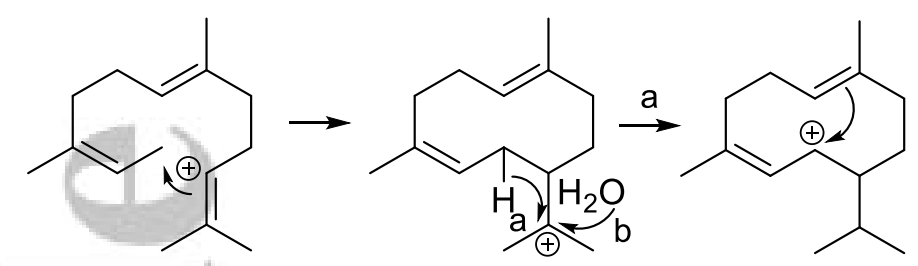

E,Z-farnesyl cation cis-germacryl cation

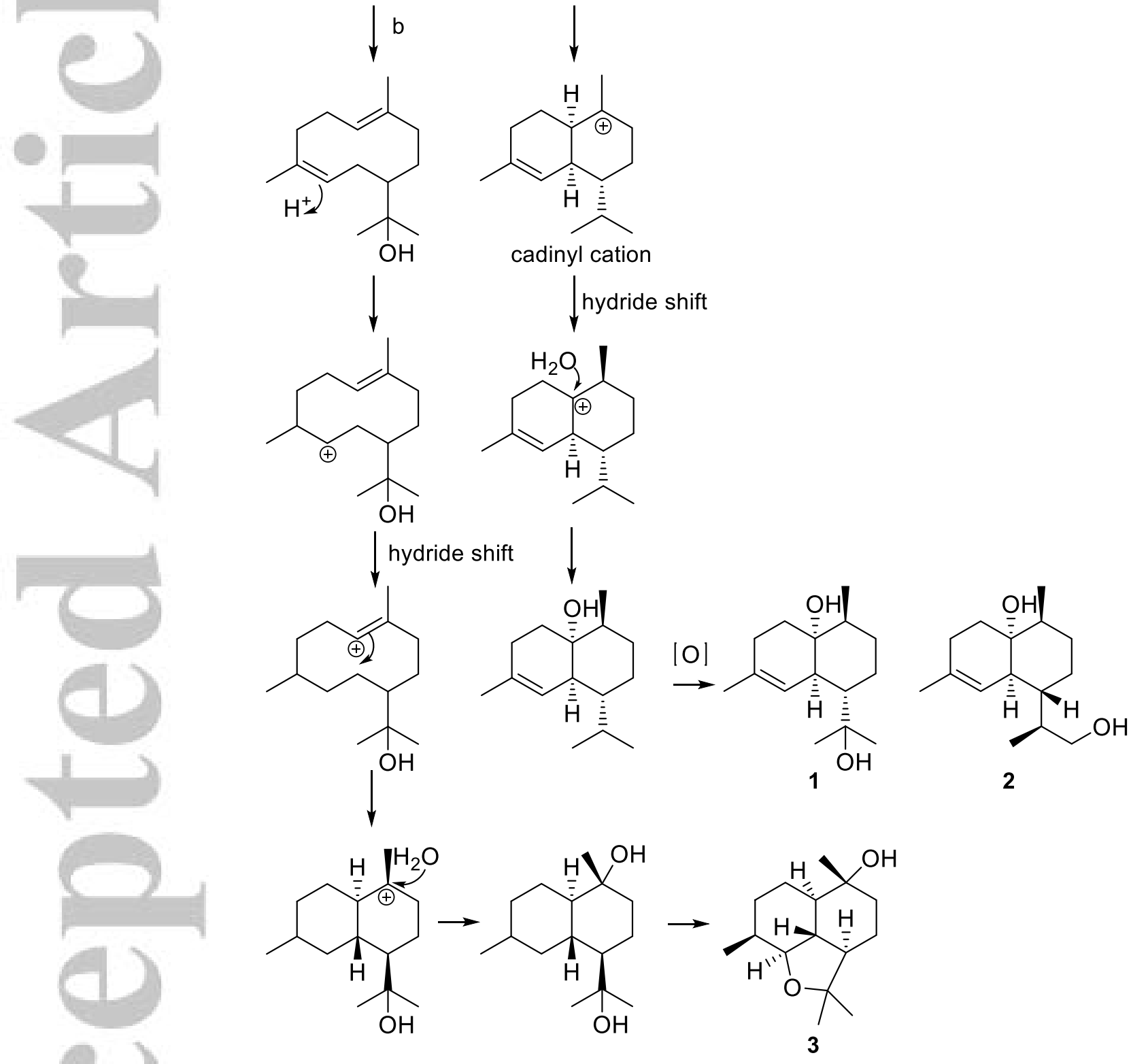

Scheme 1. Proposed biosynthetic pathway for isolated cadinane sesquiterpenes. 


\section{Graphical Abstract}

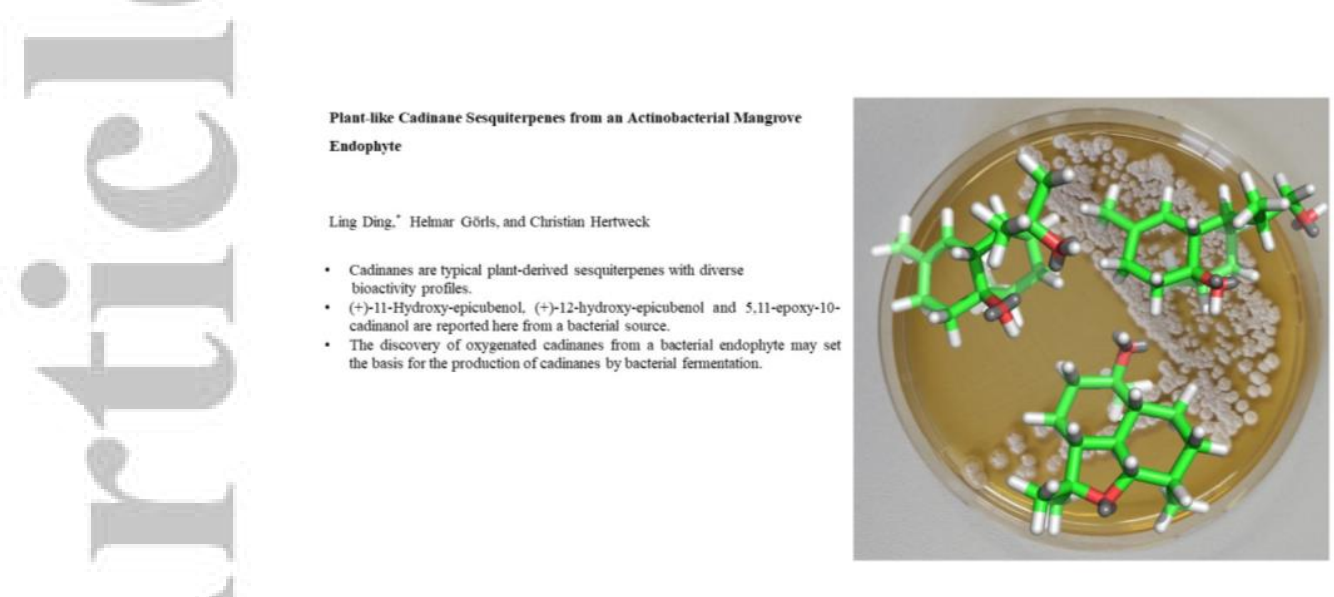

This article is protected by copyright. All rights reserved. 